\title{
DOHH Gene
}

National Cancer Institute

\section{Source}

National Cancer Institute. DOHH Gene. NCI Thesaurus. Code C91279.

This gene is involved in the hydroxylation of lysine. 